\title{
ADOPTING ENVIRONMENT RESPONSIVE STRATEGIES FOR EXISTING BUILDINGS: A PRESCRIPTIVE STUDY
}

\author{
S. BARDHAN \\ Department of Architecture, Jadavpur University, Kolkata, India.
}

\begin{abstract}
Buildings around the world are known to be highly energy intensive through their life cycle consuming about $40 \%$ of the world's primary energy supply. This is especially true for hospitality buildings, since they cannot compromise on the comfort conditions for the guests and have to ensure $24 \mathrm{~h}$ continuous energy and water supply. In urban areas, particularly with high-end tourist facilities, energy efficiency measures are widely used. However, in case of remote natural areas with erratic supply of grid electricity, use of fossil fuels for backup power supply is common. Energy efficiency measures are rare when the facility caters to budget tourists. In such cases, it is important to adopt environment-sensitive measures for the buildings so that their negative impact on nature and surrounding environment can be minimized. This paper discusses some of the strategies that can be easily integrated with existing buildings and also evaluates their economic feasibility for successful adoption. The case studies selected are typical two tourist lodges located in the coastal belt of West Bengal in India, popular for its beach tourism. Data collected on their energy and water consumption pattern have been recorded and case-specific adoption and integration of environmentally appropriate measures into the existing building forms have been identified. While further evaluation of these has shown favorable environmental impact, the cost payback analysis had different results to share. It was found that financial viability of some of the measures could not be achieved as long as the natural resources are available as free goods.
\end{abstract}

Keywords: cost payback, energy, environmental compatibility, GHG/CO $\mathrm{O}_{2}$ e emissions, solar energy, sustainability quotient, water, water harvesting, water recycling.

\section{INTRODUCTION}

The Bureau of Energy Efficiency, India [1] reports that the current electricity consumption in commercial buildings in India is about $8 \%$ of the total electricity supplied by utilities and it is growing annually by $11-12 \%$. It also identifies the hospitality sector as one of the major components of commercial buildings that consume a large amount of energy, out of which electricity accounts for more than $50 \%$ of total energy utilization. However, energy use in hospitality buildings can vary widely across regions due to climatological conditions, socio-economic class of visitors and available sources of energy in the region. The geographical location, accessibility and image of the tourist destination, in turn, influence the above factors. In this perspective, this paper covers a study of two very modest tourist lodges located in the rural belt of southern Bengal in India, more than $100 \mathrm{~km}$ from the nearest metropolitan city of Calcutta (now Kolkata) and known for its beach tourism. The climate in this region is predominantly hot-humid with a prolonged summer. The said destination is an extended part of tidal mangrove forests and is an environmentally sensitive zone, which is the basic reason of taking up this particular study. There are more than twenty tourist lodges in the locality of varying sizes and quality of services. The case studies selected are budget accommodations with both air-conditioned and non-air-conditioned rooms and were considered to be prototypes as they represented majority of the existing facilities. Evaluation of the current energy consumption pattern in these lodges has been followed by a feasibility study of adopting environment responsive strategies covering both technical and economic aspects to verify potential of their successful adoption. The tourist lodges under study, named A and B, are of about sixty bedded capacity each with slight variation in plinth areas (plinth area is defined as the covered area of a building at ground floor level including the area of its walls and structural members) and heights. However, the Lodge B was 
undergoing refurbishment to increase its capacity to one hundred. Some basic data about these lodges are shown in Table 1 as an introduction.

\section{STUDY OF ENERGY CONSUMPTION PROFILE}

The Bureau of Energy Efficiency, India undertook an initiative to sensitize the hotel industry about energy management possibilities in Indian hotels and published a baseline study on the typical energy end use in world hotels (ibid.). This was adapted to carry out the current research and analysis of energy end use in building operation for both case studies as given in Fig. 1.

\subsection{Current energy use pattern in building operation}

It was found that the electrical energy consumption in building operation was mainly for the lighting systems, cooling and heating applications and water pump. Other than electrical energy, diesel was used for back-up power supply and woody biomass from local sources for miscellaneous purposes. Natural gas was not in use in either of the case studies. The amount of biomass used in the lodges was converted into equivalent units of electricity considering its calorific value for quick reflection against Fig. 1. A comparative analysis of this energy use between A and B is presented in Table 2.

The energy footprint of these lodges were derived from the above analysis and is represented in Table 3. It shows both the total energy consumption and the electrical energy consumption.

It is to be noted that despite B having larger plinth area, it has smaller annual energy footprint. The reasons are: the built-up area is only $28 \%$ more than that of A and at the time of study, it was catering to the same number of guests. Also, the presence of dormitories in B helped it to keep its annual energy consumption under control.

Table 1: Basic data about the case studies.

\begin{tabular}{lcccc}
\hline Case study & Plinth area $\left(\mathrm{m}^{2}\right)$ & Built-up area $\left(\mathrm{m}^{2}\right)$ & No. of storey & Guest capacity \\
\hline A & 387 & 1161 & 3 & 60 \\
B & 742 & 1484 & 2 & $60+40$ \\
\hline
\end{tabular}

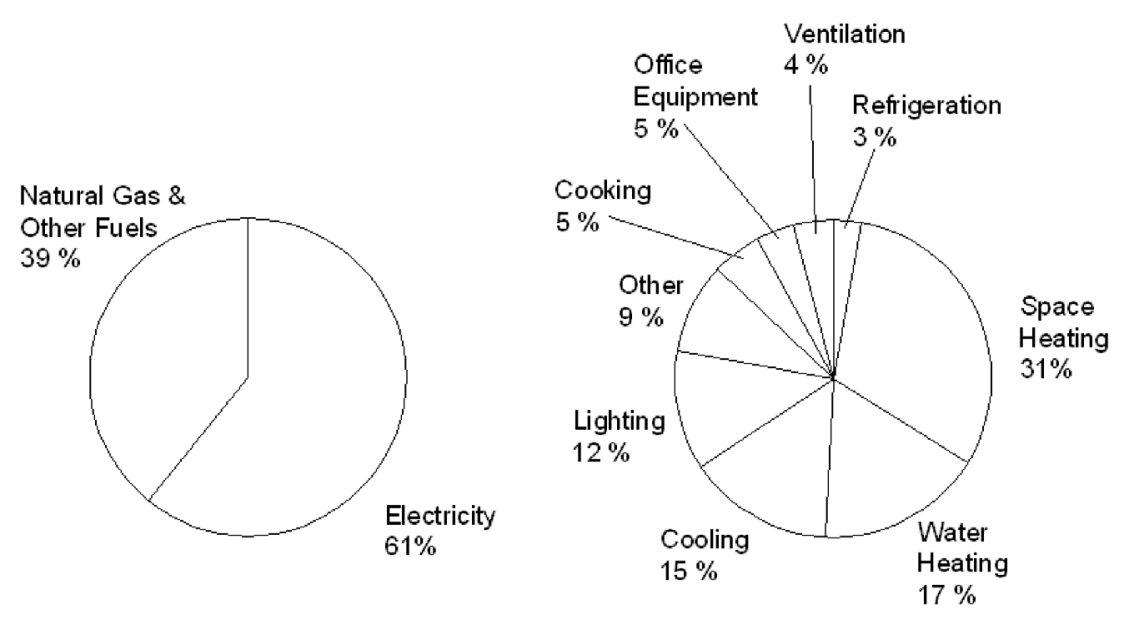

Figure 1: Energy end use pattern (world-wide average) in a typical hotel [2]. 
Table 2: Comparative break-up of energy use in building operation.

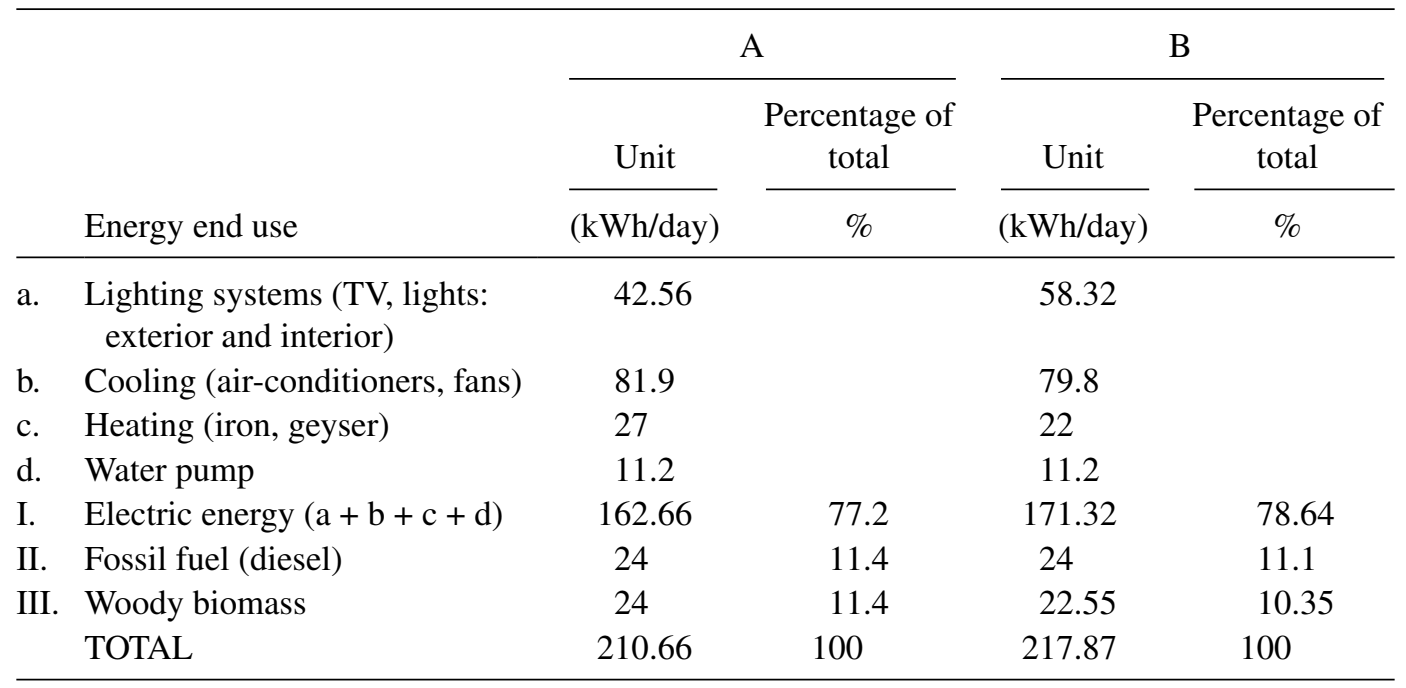

Table 3: Comparative annual energy footprint.

\begin{tabular}{|c|c|c|c|c|}
\hline & $\begin{array}{l}\text { Energy use } \\
\text { per day }\end{array}$ & $\begin{array}{c}\text { Electrical } \\
\text { energy Only }\end{array}$ & $\begin{array}{l}\text { Annual energy } \\
\text { footprint per } \\
\text { unit area }\end{array}$ & $\begin{array}{c}\text { Annual electrical } \\
\text { energy footprint } \\
\text { per unit area }\end{array}$ \\
\hline Case study & (kWh/day) & (kWh/day) & $\left(\mathrm{kWh} / \mathrm{m}^{2} /\right.$ year $)$ & $\left(\mathrm{kWh} / \mathrm{m}^{2} /\right.$ year $)$ \\
\hline A & 210.66 & 162.66 & 198.68 & 153.41 \\
\hline B & 217.87 & 171.32 & 107.17 & 84.27 \\
\hline
\end{tabular}

The annual carbon emission corresponding to the total energy used as well as electrical energy used have also been estimated with respect to emission from one unit of oil-based electricity generated [2]. The corresponding carbon emission by A for total energy used is $65357.26 \mathrm{kgC} / \mathrm{year}$ and that toward electrical energy only is $50465.26 \mathrm{kgC} /$ year. Similarly, carbon emission by B for total energy used is $67594.17 \mathrm{kgC} / \mathrm{year}$ and that toward electrical energy only is $53152.03 \mathrm{kgC} / \mathrm{year}$. This also means that A emits $14892 \mathrm{kgC} /$ year and B emits $14442.14 \mathrm{kgC} /$ year from other energy sources like fossil fuel and biomass.

\section{ADOPTION POTENTIAL OF ENVIRONMENT RESPONSIVE STRATEGIES}

Environment responsive strategies for these lodges can be either behavioral, i.e. avoiding wasteful practices or technical. The latter can be achieved in the following two ways:

- Increasing energy efficiency in all the end-use systems, i.e. lighting, cooling, heating, pumping.

- Adopting renewable energy technology to act as an alternative to conventional energy, especially electrical energy. 


\subsection{First step toward energy management: energy efficient technologies}

Studies have indicated that there is an enormous potential of saving of electricity by implementing energy efficiency in this sector. Review of international experience and several energy audit studies conducted in India indicate that hotels can effectively reduce 20-30\% of energy use without compromising the quality of hospitality services [1]. Table 4 indicates the effect of increasing energy efficiency on the current pattern of energy consumption of the case studies with a conservative estimate of $20 \%$ improvement on its electrical appliances. The carbon emission corresponding to this revised energy footprint has also been estimated with respect to emission from one unit of oil-based electricity generated [2]. It is obvious that the $20 \%$ improvement in energy efficiency translates into a simultaneous $20 \%$ reduction in the annual carbon emissions.

The first step toward energy management with efficient technologies, thus, records a $20 \%$ over-all decline in both annual energy consumption and annual carbon emission from the respective lodges.

\subsection{Second step toward energy management: renewable energy technologies}

In order to move in the direction of zero energy strategies, the diminished footprints thus obtained after achieving energy efficiency in electrical systems were believed to have further potential of reduction by adopting renewable energy technologies like solar, wind, and biogas. In Indian solar radiation condition the availability of solar power in that region is about $800 \mathrm{~W} / \mathrm{m}^{2}$ for $5 \mathrm{~h}$ duration (i.e. $4000 \mathrm{Wh} / \mathrm{m}^{2} /$ day) [3]. The solar photovoltaic (PV) modules available in the market have generation capacity around $114.27 \mathrm{~W} / \mathrm{m}^{2} / \mathrm{h}$. The approximate electricity generation capacity covering the entire roof can be calculated as (PV array area $\times 114.27 \mathrm{~W} / \mathrm{m}^{2} / \mathrm{h} \times 5 \mathrm{~h}$ )/day. Production of electricity using solar PV technology is a proven one and its integration with the existing building system is possible on the building roof itself. The electricity production using PV route will reduce the energy supplied by both electrical as well as diesel generators.

\subsubsection{Adoption potential of solar PV}

The solar PV applications generate power from the renewable source of sunshine without any noise pollution or emission. These provide a reliable solution for electricity supply in existing or

Table 4: Impact of energy management on annual energy footprint and carbon emission.

\begin{tabular}{|c|c|c|c|c|}
\hline & & a & $\mathrm{b}$ & $\mathrm{c}$ \\
\hline \multirow{3}{*}{$\begin{array}{l}\text { Case } \\
\text { study }\end{array}$} & & & $\mathrm{a} \times$ plinth area & $\mathrm{b} \times 0.85$ \\
\hline & $\begin{array}{l}\text { Annual electrical } \\
\text { energy footprint }\end{array}$ & $\begin{array}{l}\text { Annual electrical } \\
\text { energy footprint } \\
\text { with energy- } \\
\text { efficient systems }\end{array}$ & $\begin{array}{l}\text { Estimated annual } \\
\text { electrical energy } \\
\text { demand of entire } \\
\text { lodge with } \\
\text { energy-efficient } \\
\text { systems }\end{array}$ & $\begin{array}{l}\text { Annual carbon } \\
\text { emission from } \\
\text { electrical energy } \\
\text { consumption by } \\
\text { energy-efficient } \\
\text { systems }\end{array}$ \\
\hline & $\left(\mathrm{kWh} / \mathrm{m}^{2} /\right.$ year $)$ & $\left(\mathrm{kWh} / \mathrm{m}^{2} /\right.$ year $)$ & (kWh/year) & (kgC/year) \\
\hline A & 153.41 & 122.73 & 47496.51 & 40372 \\
\hline B & 84.27 & 67.42 & 50025.64 & 42521.8 \\
\hline
\end{tabular}


planned tourist resorts with or without electrical grid since no additional land and water is needed. The following section discusses the retrofitting possibilities of this system in the study area for the two case study facilities. The PV generators can be installed over the roof of both case studies facing the south-east direction and at an inclination of $22.5^{\circ}$ in order to produce the maximum electricity, designed for a nominal voltage of $24 \mathrm{~V}$. In this study, the PV modules were considered to be fixed in continuous rows on an overhead structural frame retrofitted on the roof of the lodge. Much like roof tiles, the solar PV collector area becomes equal to the respective roof area and this also creates an additional floor with the PV array on top as the virtual roof. It was further assumed that the solar PV would not only have necessary Balance of Systems (BoS) including battery backup to enable power consumption at source, but also be simultaneously grid tied with appropriate protection systems, so that it can transfer the excess power to the grid during lean tourist seasons. Considering 80 rainy days [4] and another 40 overcast days in the region, about 245 sunny and dry days in a calendar year may be assumed to have solar power generation potential.

The long-term benefit associated with this adaptation is of course reduction in $\mathrm{CO}_{2}$ emission, which will be to the tune of $187 \mathrm{kgC} /$ day or 68.25 tonnes of $\mathrm{CO}_{2}$ per year by Lodge A, equivalent to a savings of 25.756 Cum of diesel fuel per year, considering the total energy use by it [5]. The comparative results of environmental benefits from architectural integration of solar PVs in the lodges A and $\mathrm{B}$ are shown in Table 5.

Lodge B will potentially enjoy a higher surplus solar power owing to its larger roof area offering a bigger solar PV installation area, though the initial investment cost will also be higher for B.

However, the energy involvement in the production process of the most common type of module, which uses multi-crystalline silicon, releases $37 \mathrm{~g} / \mathrm{kWh}$ of greenhouse gases of $\mathrm{CO}_{2}$ equivalent to the atmosphere [2]. Therefore, the captive $\mathrm{CO}_{2}$ emission component within the solar modules for generation of the potential solar power will have to be considered. Hence, a more detailed analysis was carried out to find the net environmental benefits achievable for the tourist Lodge A. Similar study and analysis exercise was carried out for the second case study, i.e. B, having a roof area of $741.66 \mathrm{~m}^{2}$. Like A, calculations in this case were also based on the assumption that the entire roof area will be covered by solar PV modules to maximize the energy output possible from the facility. The results are presented in Table 6.

Table 5: Environmental benefits from solar PV integration to the existing structures.

\begin{tabular}{|c|c|c|c|c|c|}
\hline & $\mathrm{a}$ & $\mathrm{b}$ & $\mathrm{c}$ & $\mathrm{D}$ & $\mathrm{e}$ \\
\hline & \multirow[b]{2}{*}{$\begin{array}{l}\text { Roof } \\
\text { area }\end{array}$} & \multirow[b]{2}{*}{$\begin{array}{l}\text { Power generation } \\
\text { potential from entire } \\
\text { lodge per day }\end{array}$} & $(b \times 245)$ & Refer Table 4 & $(c-d)$ \\
\hline & & & $\begin{array}{c}\text { Average power } \\
\text { generation potential } \\
\text { per year from entire } \\
\text { lodge (considering } 245 \\
\text { sunny days) }\end{array}$ & $\begin{array}{l}\text { Estimated annual } \\
\text { electrical energy } \\
\text { demand of entire } \\
\text { lodge with energy- } \\
\text { efficient systems }\end{array}$ & $\begin{array}{c}\text { Surplus energy } \\
\text { available with } \\
\text { case studies }\end{array}$ \\
\hline & $\mathrm{m}^{2}$ & (kWh/day) & (kWh/year) & (kWh/year) & (kWh/year) \\
\hline A & 387 & 221 & 54145 & 47496.51 & 6648.49 \\
\hline B & 742 & 424 & 103880 & 50025.64 & 53854.36 \\
\hline
\end{tabular}


Table 6: Net carbon emission negation potential from solar PV adoption.

\begin{tabular}{|c|c|c|c|c|}
\hline & A & $\mathrm{b}$ & $\mathrm{c}$ & d \\
\hline & Refer Table 5 & $(\mathrm{a} \times 0.85)$ & $(a \times 0.037)$ & $(b-c) \times 365$ \\
\hline & $\begin{array}{l}\text { Average power generation } \\
\text { potential per year from } \\
\text { entire lodge (considering } \\
245 \text { sunny days) }\end{array}$ & $\begin{array}{l}\text { Reduction potential of } \\
\mathrm{CO}_{2} \text { emission through } \\
\text { solar PV installation }\end{array}$ & $\begin{array}{l}\text { Captive emission } \\
\text { component of the } \\
\text { installed solar PVs }\end{array}$ & $\begin{array}{c}\text { Net annual negation } \\
\text { in carbon emission } \\
\text { from solar PV per } \\
\text { year }\end{array}$ \\
\hline & (kWh/year) & $\mathrm{kgC/year}$ & $\mathrm{kgC/year}$ & $\mathrm{kgC/year}$ \\
\hline A & 54145 & 46023.25 & 2003.36 & 44019.89 \\
\hline B & 103880 & 88298 & 3843.56 & 84454.44 \\
\hline
\end{tabular}

Table 7: Gross carbon emission negation potential from solar PV adoption.

\begin{tabular}{|c|c|c|c|c|c|}
\hline & \multirow[t]{2}{*}{$\mathrm{a}$} & \multirow[t]{2}{*}{$\mathrm{b}$} & $\mathrm{c}$ & $\mathrm{d}$ & \multirow[t]{2}{*}{$\mathrm{e}=\mathrm{c}-\mathrm{d}$} \\
\hline & & & $(a+b)$ & Refer Table 6 & \\
\hline & $\begin{array}{l}\text { Annual carbon } \\
\text { emission from } \\
\text { other energy } \\
\text { sources (fossil } \\
\text { fuel \& biomass) }\end{array}$ & $\begin{array}{l}\text { Revised annual } \\
\text { carbon emission } \\
\text { from electrical } \\
\text { energy (post- } \\
\text { energy } \\
\text { efficiency) }\end{array}$ & $\begin{array}{l}\text { Total annual } \\
\text { carbon emission } \\
\text { from all energy } \\
\text { sources }\end{array}$ & $\begin{array}{l}\text { Gross annual } \\
\text { negation in } \\
\text { carbon emission } \\
\text { from solar PV } \\
\text { per year }\end{array}$ & $\begin{array}{l}\text { Balance } \mathrm{CO}_{2} \\
\text { emission to be } \\
\text { offset by other } \\
\text { retrofitting } \\
\text { options }\end{array}$ \\
\hline & kgC/year & kgC/year & kgC/year & kgC/year & kgC/year \\
\hline A & 14892 & 40372 & 55264 & 44019.89 & 11244.11 \\
\hline B & 14442.14 & 42521.8 & 56963.94 & 84454.44 & $\begin{array}{l}\text { (-) } 27490.5 \\
\text { Complete negation }\end{array}$ \\
\hline
\end{tabular}

The status of $\mathrm{CO}_{2}$ sequestration of the respective lodges after installation of solar PV modules as part of second-stage energy management was checked on the basis of above findings and is presented below in Table 7.

Further analysis reveals that while A can sequester $80 \%$ of its annual $\mathrm{CO}_{2}$ emission through architectural integration of solar PV modules alone, B actually succeeds in not only achieving $100 \%$ of its present demands, but can offset emissions released from the surroundings. However, once B starts functioning at its full capacity, the emission scenario would get similar to A.

\subsubsection{Adoption potential for solar thermal}

Solar thermal (ST) technologies are not yet playing the important role they deserve in the reduction of buildings' fossil fuel consumption and consequent greenhouse gas emissions, even though the oil price has recently seen steep increase. The retrofit possibilities of building integrated solar thermal (BIST) in the existing tourist facilities were investigated for potential successful integration. The ST 
products commercially available in the market with the flat plate collector system offer integration solutions either with the façade or on the roof itself. Since, the roof has already been considered for the solar PV modules, the possible building components that can accommodate the ST collectors are the roof parapet walls with high solar exposure or the south-facing building façade, which in both cases is advantageously the rear façade.

Water heating in hotels is needed for guestrooms, laundry, public restrooms, janitorial work, kitchens, locker room showers, and occasionally swimming pools. Water heating can be a relatively large energy user in hotels, particularly when laundry is done on-site [1]. In the current case studies, the use of ST for producing hot water to the guests will be mostly applied to meet their bathing water demand. Studies on water use pattern shows that about $30 \%$ of the per capita water consumption accounts for bathing, which comes to about $0.3 \times 0.180$ Cum or 0.054 per capita per day. For A, this comes to $(64 \times 0.054)=3.456 \mathrm{Cum} /$ day and for B, it is $(60 \times 0.054)=3.240 \mathrm{Cum} /$ day. In order to find out the energy required to heat this volume of water, the following assumptions were made:

- Since hot water requirement is mostly during the winters, i.e. October to February only, the average number of days requiring heating of water has been considered to be 150 .

- Temperature of water in winters is $20^{\circ} \mathrm{C}$.

- Under local climatic conditions, especially for sea-side warm locales, temperature of heated water for bathing purpose at comfort level is $26^{\circ} \mathrm{C}$.

Since $1 \mathrm{Calorie}$ of heat energy is required to raise $1 \mathrm{~g}$ ( or $1 \mathrm{cc}$ ) of water by $1^{\circ} \mathrm{C}$, to raise the temperature of $3.456 \mathrm{Cum}$ of water by $(26-20)=6^{\circ} \mathrm{C},\left\{\left(3.456 \times 10^{6}\right) \mathrm{cc} \times 6\right\}=20736 \times 10^{3}$ Calories or $\left(20736 \times 10^{3} \times 1.16 \times 10^{-6}\right)=24 \mathrm{kWh}$ of energy would be required per day for A. Similar calculations for B show the energy requirement to be $22.55 \mathrm{kWh} /$ day. IEEE [2] specifies greenhouse gas emission to be $45 \mathrm{~g} / \mathrm{kWh}$ of $\mathrm{CO}_{2}$ equivalent for biomass-based fossil fuel form of energy supply. Since the energy needed for heating water is at present being met by using biomass, the corresponding $\mathrm{CO}_{2}$ emission for 150 days can be calculated as $(24 \times 0.045 \times 150)=162 \mathrm{kgC} / \mathrm{year}$ for $\mathrm{A}$ and $(22.55 \times 0.045 \times 150)=152.21 \mathrm{kgC} /$ year for B.

Again, the total bathing water requirements were assessed vis-à-vis capacity of the STs to check the technical feasibility of architectural integration in these lodges. Table 8 gives a quantitative assessment of the ST adaptation and the associated benefits arising from it. These benefits manifest in two forms: one, avoiding biomass-based energy consumption (1 Calorie of heat energy is required to raise $1 \mathrm{~g}$ (or $1 \mathrm{cc}$ ) of water by $1^{\circ} \mathrm{C}$. For raising the temperature of $3.456 \mathrm{Cum}$ of water by $(26-20)=6^{\circ} \mathrm{C}$, $\left(3.456 \times 10^{6} \times 6\right)=20736 \times 10^{3}$ Calories or $\left(20736 \times 10^{3} \times 1.16 \times 10^{-6}\right)=24 \mathrm{kWh} /$ day $)$ along with its subsequent $\mathrm{CO}_{2}$ emission (as shown in the above calculations) and two, preventing biomass burning and thus, saving the biomass itself. This implies saving of trees, which in turn will help in fixing the atmospheric $\mathrm{CO}_{2}$. These have been tabulated below under 'Direct' and 'Indirect' environmental benefits in Tables 8 and 9, respectively.

A $2.0 \mathrm{~m} \times 2.0 \mathrm{~m}$ collector would yield $0.1 \mathrm{Cum}$ of hot water at $65^{\circ} \mathrm{C}$ every $3.5 \mathrm{~h}$, i.e. effectively 1 day. This volume of water is equivalent to $0.6 \mathrm{Cum}$ of usable water. Above calculations show that 6 nos. of solar panels are sufficient to yield the required water. This means $6 \times 2 \mathrm{~m}=12 \mathrm{RM}$ (running meter) length of roof parapet can be utilized for this purpose. For façade integration, $6 \times 4 \mathrm{~m}^{2}=$ $24 \mathrm{~m}^{2}$ area can also be considered as an alternative to the parapet option. However, from maintenance and servicing point of view, the former appears more convenient and viable than the latter. For both A and B, the said number of collectors with the above dimensions can be easily accommodated on the roof parapet. 
Table 8: Direct environmental benefits from ST integration.

\begin{tabular}{cccccc}
\hline & $\mathrm{a}$ & $\mathrm{b}$ & $\mathrm{c}=\mathrm{a} / \mathrm{b}$ & $\mathrm{d}$ & $\mathrm{e}=(\mathrm{d} \times 0.045) \times$ \\
150
\end{tabular}

*At current consumption rate.

**Likely to increase in future.

Table 9: Indirect environmental benefits from ST integration.

\begin{tabular}{|c|c|c|c|c|}
\hline & $\mathrm{a}$ & $\mathrm{b}$ & $\mathrm{c}=\mathrm{b} / 148.36$ & $\mathrm{~d}=\mathrm{c} \times 24.3$ \\
\hline & $\begin{array}{l}\text { Equivalent energy } \\
\text { saved through ST }\end{array}$ & $\begin{array}{l}\text { Biomass required for } \\
\text { heating the same } \\
\text { volume }\end{array}$ & $\begin{array}{l}\text { Saving of precious } \\
\text { trees at } 148.36 \mathrm{~kg} / \text { tree }\end{array}$ & $\begin{array}{l}\text { Carbon Sequestered } \\
\text { by the saved biomass }\end{array}$ \\
\hline & kWh/day & $\mathrm{kg} /$ year & Nos./year & $\mathrm{kgC} / \mathrm{yr}$ \\
\hline A & 24 & 810 & 6 & 246.15 \\
\hline B & 22.55 & 765 & 5 & 246.15 \\
\hline
\end{tabular}

Assessment of indirect environmental benefits involves complex calculations at multiple stages. Stage one involves finding out the annual quantity of biomass required to generate the energy needed for heating water. Stage two involves translating that biomass quantity into the actual number of trees being felled annually to supply the said amount. Stage three involves quantification of the $\mathrm{CO}_{2}$ fixed by such trees, if retained, and contribute in negating global warming effect.

\subsubsection{Stage one: finding out the annual quantity of biomass used}

The studies made by Dias and Pooliyadda [6] specify the TOE (tonnes of oil equivalent) of biomass, mainly firewood to be 0.38 , where one TOE $=41.84 \mathrm{GJ}$, meaning 1 tonne of firewood will consume $(0.38 \times 41.84 \mathrm{GJ})=15.9 \mathrm{GJ}$ of energy, the amount of biomass required to meet the previously stated energy demand for hot water production was found out.

In other words, $15.9 \mathrm{GJ}$ or $4420 \mathrm{kWh}$ energy will be produced by $1000 \mathrm{~kg}$ of biomass or $4.42 \mathrm{kWh}$ of energy will be produced by $1 \mathrm{~kg}$ of biomass. This is also at par with the research findings of Karmakar [7] who estimated $1 \mathrm{~kg}$ of Avicennia species - the common firewood of the region - generates about 4000 kilocalories of heat, which is equivalent to $4.64 \mathrm{kWh}$ of energy. This formed the basis 
Table 10: Gross carbon negation potential from ST adoption.

\begin{tabular}{cccc}
\hline & $\mathrm{a}$ & $\mathrm{b}$ & $\mathrm{c}=\mathrm{a}+\mathrm{b}$ \\
\hline $\begin{array}{c}\text { Direct negation in carbon } \\
\text { emission by ST (as per column } \\
\text { 'e' of Table 8) }\end{array}$ & $\begin{array}{c}\text { Carbon sequestered by the saved } \\
\text { biomass producing trees (as per } \\
\text { column 'd' of Table 9) }\end{array}$ & $\begin{array}{c}\text { Total carbon } \\
\text { negation by ST }\end{array}$ \\
\cline { 2 - 3 } & kgC/year & kgC/year & $\mathrm{kgC/year}$ \\
\hline $\mathrm{A}$ & 162 & 246.15 & 408.15 \\
$\mathrm{~B}$ & 152.21 & 246.15 & 398.36 \\
\hline
\end{tabular}

for estimating the amount of biomass required for heating water at the two lodges. For Balaka Lodge A, where the daily energy demand is $24 \mathrm{kWh}$, biomass consumption is about (24/4.42) or 5.4 $\mathrm{kg} / \mathrm{day}$, while for Bay View Lodge B with $22.55 \mathrm{kWh}$ of daily energy requirement, biomass consumption is (22.55/4.42) or $5.1 \mathrm{~kg} /$ day.

Hence, the annual consumption of biomass (i.e. for 150 days of the winters) for Lodge A will be $(5.4 \times 150)=810 \mathrm{~kg} /$ year and that of Lodge $\mathrm{B}$ will be $(5.1 \times 150)=765 \mathrm{~kg} /$ year.

\subsubsection{Stage two: finding out the equivalent number of trees}

Converting these values into actual number of trees is again an assumption-based process, the rationale being effective biomass can be obtained from a matured tree of about $300 \mathrm{~mm}$ trunk girth and $3.5 \mathrm{~m}$ height.

The volume of such tree (of height less than $3.9 \mathrm{~m}$ ) can then be calculated as $\left(\pi \mathrm{r}^{2} \mathrm{~h}\right)$ as given by Karmakar [7] where $\mathrm{r}=$ radius of the tree girth and $\mathrm{h}=$ height of the tree or $\left(3.14 \times 0.15^{2} \times 3.5\right)=$ 0.247 Cum or $\left(0.247 \times 10^{6}\right) \mathrm{cm}^{3}$. Considering density of matured mangrove wood to be varying between 0.5 and $0.7 \mathrm{~g} / \mathrm{cm}^{3}$ [7] or an average of $0.6 \mathrm{~g} / \mathrm{cm}^{3}$, the weight of each tree producing this wood will be $\left\{\left(0.247 \times 10^{6}\right) \times 0.6\right\} \mathrm{g}$ or $148.36 \mathrm{~kg}$.

The number of trees felled to supply the biomass of $810 \mathrm{~kg} / \mathrm{year}$ to Lodge A means $(810 / 148.36)=$ 5.46 or $\approx 6$ nos. and that for Lodge B at current rate of consumption is $(765 / 148.36) \approx 5$ nos.

\subsubsection{Stage three: finding out the carbon sequestered by the biomass equivalent trees}

It has been reported by Karmakar [7] that the carbon assimilation efficiency of Avicennia dominated mangrove ecosystem is 54.75 tonnes of carbon/hectare/year against the average value of mixed mangrove forest as 27 tonnes of carbon/hectare /year. Since the Avicennia species are the most preferred firewood, the former value has been considered here, i.e. $5.47 \mathrm{kgC} / \mathrm{m}^{2} /$ year.

Considering an average Avicennia tree canopy to be $3.0 \mathrm{~m}$, each such tree will occupy $3 \times 3=$ $9 \mathrm{~m}^{2}$ area of forested land. Therefore, each such tree will be able to fix $5.47 \times 9=49.23 \mathrm{kgC} /$ year. Hence, the 5 nos. of trees will sequester a total of $(5 \times 49.23)=246.15 \mathrm{kgC} / \mathrm{year}$.

All the above findings are tabulated in Table 9 as indirect environmental gain.

The direct and indirect environmental benefits are summarized in Table 10 and the cumulative benefit in terms of total $\mathrm{CO}_{2}$ offsetting achieved by retrofitting ST technology for providing hot bathing water to the tourists has been enumerated for both the facilities.

\section{COMPREHENSIVE CARBON AUDIT}

With the above discussions on architectural adoption of environmentally responsive measures suggested for the case studies to increase their environmental compatibility, it was important to look 
Table 11: Summary: modified carbon footprint.

\begin{tabular}{|c|c|c|c|c|c|}
\hline & Carbondebit & & Carbon credit & & Carbon balance \\
\hline & $\mathrm{A}$ & $\mathrm{b}$ & $\mathrm{c}$ & $d=(b+c)$ & $d-a$ \\
\hline & $\begin{array}{l}\text { Annual carbon } \\
\text { emission }\end{array}$ & $\begin{array}{c}\text { Carbon negation } \\
\text { by solar PV }\end{array}$ & $\begin{array}{l}\text { Total carbon negation } \\
\text { (direct and indirect) by } \\
\text { ST }\end{array}$ & $\begin{array}{c}\text { Total carbon } \\
\text { negated }\end{array}$ & Debit/Credit \\
\hline & $\mathrm{kgC/year}$ & $\mathrm{kgC/year}$ & $\mathrm{kgC/year}$ & $\mathrm{kgC/year}$ & \\
\hline A & 55264 & 44019.89 & 408.15 & 44428.04 & 10835.96 debit \\
\hline B & 56963.94 & 84454.44 & 398.36 & 84852.8 & 27888.86 credit \\
\hline
\end{tabular}

into the collective impact of these in the form of the modified carbon footprint. It is interesting to note that the carbon balance sheet has yielded high positive results with credit in carbon account for Lodge B, as indicated in Table 11 .

The post-adoption reduction of carbon footprint of these two lodges establishes the potentiality of environmentally responsive measures like increased energy efficiency and renewable technologies as technically feasible and environmentally suitable. However, successful implementation and social acceptance of these measures depend on their economic viability. Therefore, the next section takes up an analysis of the cost payback period of these measures to understand their financial implications.

\section{ASSESSMENT OF COST PAYBACK PERIOD}

The initial investment in solar PV will involve cost of module and that of BoS covering battery, storage, and infrastructure cost. The operational life of solar PV has been considered to be 25 years. The calculation of investment on solar PV for one life cycle is based on the power generation potential of Lodge A as $221 \mathrm{kWh} /$ day and that of Lodge B as $424 \mathrm{kWh} /$ day against their daily energy consumptions after implementing energy-efficiency measures to be about 130 and $137 \mathrm{kWh} / \mathrm{day}$, respectively. Battery back-up system of solar panels needs to be provided for this power component, while the surplus power generated from the photo-voltaic modules can be fed to the grid directly and recover the cost. The financial rates as per the current practice have been considered for calculations of both investment and cost pay back.

Considering INR 300 per Peak Watt, the investment in solar PV for one life cycle or 25 years for Lodge A is estimated at INR 13,260,000 and Lodge B at INR 25,440,000. It is also possible to calculate the unit cost (INR/kWh) of solar power generated from the PVs and can be given by total investment (INR) divided by the product of one life cycle (no. of years) and annual power generation potential (kWh/year). Such analysis shows that it is about INR 6.60 for both A and B, which is absolutely reasonable compared with the conventional grid power generation cost.

Thus, the cost payback analyses for solar PV integration for both Lodge A and Lodge B indicate high financial viability. Payback period in case of Lodge B is less because of its lower energy consumption in proportion to the built-up area $\left(\mathrm{kWh} / \mathrm{m}^{2} /\right.$ day), which is just $0.2 \mathrm{kWh} / \mathrm{m}^{2} /$ day at the time of the study, compared with that of A, which is $0.33 \mathrm{kWh} / \mathrm{m}^{2} /$ day. It may be interesting to note that in India, primary energy sources needed to produce electricity is about 4.2 times the end-use final electricity consumption [12]. This high primary energy conversion factor is mainly accounted for 
Table 12: Return from solar PVs for one life cycle (25 years).

\begin{tabular}{|c|c|c|c|c|c|c|}
\hline & $\mathrm{a}$ & $\mathrm{b}$ & $\mathrm{c}$ & d & $\begin{array}{c}e=a+b+ \\
c+d\end{array}$ & \multirow[b]{2}{*}{$\begin{array}{l}\text { Cost payback } \\
\text { period (years) }\end{array}$} \\
\hline & $\begin{array}{l}\text { Savings in } \\
\text { electricity bill } \\
\text { per year [8] }\end{array}$ & $\begin{array}{c}\text { Savings in } \\
\text { diesel con- } \\
\text { sumption per } \\
\text { year }\end{array}$ & $\begin{array}{l}\text { Revenue } \\
\text { generation by } \\
\text { feeding the } \\
\text { surplus power } \\
\text { into grid per } \\
\text { year }\end{array}$ & $\begin{array}{l}\text { Credit for the } \\
\text { net } \mathrm{CO}_{2} \\
\text { sequestration } \\
\text { per year }\end{array}$ & $\begin{array}{c}\text { Total gain per } \\
\text { year (INR/ } \\
\text { year) }\end{array}$ & \\
\hline \multirow[t]{2}{*}{ A } & $\begin{array}{l}\text { @ 6000/- per } \\
\text { month }\end{array}$ & $\begin{array}{l}\text { @ } 2 \mathrm{~h} \text { of } \mathrm{DG} \\
\text { running, i.e. } \\
8.33 \mathrm{kWh} \text { of } \\
\text { energy/day }\end{array}$ & $\begin{array}{l}\text { @ INR 16.13/ } \\
\text { kWh of en- } \\
\text { ergy produced } \\
\text { [9] }\end{array}$ & $\begin{array}{l}\text { @ } 12 \text { Euro or } \\
\text { INR } 720 / \text { per } \\
\text { tonne of } \mathrm{CO}_{2} \\
\text { equivalent } \\
\text { [10] }\end{array}$ & & \\
\hline & $\begin{array}{l}6000 \times 12= \\
72000 /-\end{array}$ & $\begin{array}{l}8.33 \times 365 \\
=3041.66 \\
\mathrm{kWh} / \text { year } \\
(3041.66 \times \\
54) / 200[11] \\
=821.25 \mathrm{~L} \\
821.25 \times 40 /- \\
=32850 /-\end{array}$ & $\begin{array}{l}221-130=91 \\
\mathrm{kWh} / \text { day } \\
\\
91 \times 365= \\
33215 \mathrm{kWh} / \\
\text { year } \\
33215 \mathrm{kWh} \\
\times 16.13 /-= \\
535758 /-\end{array}$ & $\begin{array}{c}(44.428 \mathrm{mT} \\
\times 720 /-)= \\
31988 /-\end{array}$ & $\begin{array}{l}\text { 600596/-per } \\
\text { year }\end{array}$ & 22 years \\
\hline \multirow[t]{3}{*}{ B } & $\begin{array}{l}\text { @ 12000/- per } \\
\text { month }\end{array}$ & $\begin{array}{l}\text { @ } 150 \text { L per } \\
\text { month }\end{array}$ & $\begin{array}{l}424-137= \\
287 \mathrm{kWh} / \text { day }\end{array}$ & & & \\
\hline & & $\begin{array}{l}150 \times 12= \\
1800 \mathrm{~L} / \text { year }\end{array}$ & $\begin{array}{l}287 \times 365= \\
104755 \mathrm{kWh} / \\
\text { year }\end{array}$ & & & \\
\hline & $\begin{array}{c}12000 \times 12= \\
144000 /-\end{array}$ & $\begin{array}{l}1800 \times 40 /-= \\
72000 /-\end{array}$ & $\begin{array}{c}104755 \times \\
16.13 /-= \\
1689698 /-\end{array}$ & $\begin{array}{c}(84.852 \mathrm{mT} \\
\times 720 /-)= \\
61093.44 /-\end{array}$ & $\begin{array}{l}\text { 1822791.44/- } \\
\text { per year }\end{array}$ & 13.95 years \\
\hline
\end{tabular}

significant distribution and transmission (T\&D) as well as commercial losses (31\%) and second, a sizable generation (82\%) from fuel combustion at low efficiency (26\% for coal, $28 \%$ for oil, and $41 \%$ for gas). However, the same exercise for ST flat plate collector system did not yield positive results, especially because of easy availability of biomass from local sources at very cheap prices.

\section{CONCLUSION}

Energy is one of the few key drivers of development and therefore, is the center of attention in an increasingly energy-constrained world. Energy demand in commercial buildings is a matter of concern in every part of the world and the stakeholders along with the scientific community are looking for green energy options to meet this need. This paper presents a study of two modest tourist lodges 
in a coastal Indian location that primarily includes three stages: i) mapping of their existing pattern of energy use, ii) assessing the potential of achieving energy efficiency with the same power supply source, i.e. fossil fuel, and iii) evaluating the technical and environmental feasibility of solar PV and ST integration in their respective structures. The fourth and final stage includes financial analyses of both these measures to understand the strength and success - ability of the recommendations. The result of the fourfold analyses has emerged to be highly positive with substantial reduction in carbon footprint as well as economic viability for solar PV with a promise of the same for ST too, subject to a high pricing of natural resources in the not-so-distant future.

\section{ACKNOWLEDGEMENT}

The author is grateful to All India Council for Technical Education (AICTE) for its financial support in carrying out this study.

\section{REFERENCES}

[1] Guidebook on Energy Management in your Hotel, Bureau of Energy Efficiency, Ministry of Power, Govt. of India, pp. 3 \& 8, 2008, http://www.bee-india.nic.in/.

[2] IEEE Spectrum, Issue: February 2008, 45(2), p. 56, 2008.

[3] Field Station Data, School of Energy Studies, Jadavpur University, 2004.

[4] Mishra, S., Weather and Climate of West Bengal, http://www.banglarmukh.com/

[5] Bardhan, S., et al. Retrofitting potential of an existing tourist lodge for improved environmental performance: an investigation, The Sustainable World, ed. C.A. Brebbia, WIT Press: Southampton and Boston, pp. 759-770, 2010.

[6] Dias, W.P.S. \& Pooliyadda, S.P., Quality based energy contents and carbon coefficients for Building materials: a systems approach. Energy, 29, pp. 561-580, 2004. doi: http://dx.doi. org/10.1016/j.energy.2003.10.001

[7] Karmakar, S., Study of mangrove biomass, net primary production \& species distribution using optical and microwave remote sensing data, M. Tech. Thesis, Andhra University: India, pp. $36 \& 40,2006$.

[8] Bardhan, S., Carbon foot-print studies and sustainable architectural concepts for coastal ecotourism, Doctoral Thesis, Jadavpur University, 2008.

[9] Rate finalized by Calcutta Electricity Supply Corporation (CESC) for feeding into grid.

[10] http://www.carbonpositive.net/viewarticle.aspx?articleID=2069 [accessed 15th August 2010 12:53].

[11] Ghosh, B., Towards Modernized Bio-Energy, Ministry of New and Renewable Energy, Govt. of India, 2004.

[12] De la Rue du Can, S., McNeil, M. \& Sathaye, J., India Energy Outlook: End Use Demand in India to 2020, Environmental Energy Technologies Division, Ernest Orlando Lawrence Berkeley National Laboratory: USA, 2009. 